University of Nebraska - Lincoln

DigitalCommons@University of Nebraska - Lincoln

Agronomy \& Horticulture -- Faculty Publications

Agronomy and Horticulture Department

$1-1981$

\title{
Divergent Selection for In Vitro Dry Matter Digestibility in Switchgrass
}

\author{
K. P. Vogel \\ United States Department of Agriculture, kvogel1@unl.edu \\ Francis A. Haskins \\ University of Nebraska-Lincoln, fhaskins@neb.rr.com \\ Herman J. Gorz \\ United States Department of Agriculture
}

Follow this and additional works at: https://digitalcommons.unl.edu/agronomyfacpub

Part of the Plant Sciences Commons

Vogel, K. P.; Haskins, Francis A.; and Gorz, Herman J., "Divergent Selection for In Vitro Dry Matter Digestibility in Switchgrass" (1981). Agronomy \& Horticulture -- Faculty Publications. 247.

https://digitalcommons.unl.edu/agronomyfacpub/247

This Article is brought to you for free and open access by the Agronomy and Horticulture Department at DigitalCommons@University of Nebraska - Lincoln. It has been accepted for inclusion in Agronomy \& Horticulture -Faculty Publications by an authorized administrator of DigitalCommons@University of Nebraska - Lincoln. 


\title{
Divergent Selection for In Vitro Dry Matter Digestibility in Switchgrass ${ }^{1}$
}

\author{
K. P. Vogel, F. A. Haskins, and H. J. Gorz ${ }^{2}$
}

\begin{abstract}
The purposes of this study were to determine if phenotypic selection for in vitro dry matter digestibility (IVDMD) could be used to improve the IVDMD for switchgrass (Panicum virgatum L.) and to obtain heritability estimates of IVDMD in switchgrass. In 1973 a selection nursery of over 2,200 plants was established with transplanted seedlings of two similar Nebraska experimental strains. In 1974 about 800 plants that appeared to be agronomically superior were sampled for IVDMD. Single-plant selections for high and low IVDMD were made in each of the nursery rows. In 1976, ramets from 25 of the high-IVDMD selections and from 25 of the low-IVDMD selections were transplanted to establish isolated high- and lowIVDMD polycross (PC) nurseries. Seed harvested from these nurseries in 1977 and from the same openpollinated (OP) clones in the selection nursery in 1976 was used in 1978 to establish a replicated seeded sward nursery in which the following strains were compared: high IVDMD PC, high IVDMD OP, 'Pathfinder,' low IVDMD OP, and low IVDMD PC. Forage yields and IVDMD were measured in 1978 and 1979 . Over the 2 years the strains averaged $51.5,50.0,49.4,48.3$, and $48.1 \%$ IVDMD, respectively. The high IVDMD PC strain was significantly higher in IVDMD than the other strains in both years. Realized heritabilities for high and low IVDMD were 0.59 and 0.55 , respectively. Strains did not differ significantly for forage yield in either year; thus, the gain in IVDMD by breeding was achieved without any yield loss.
\end{abstract}

Additional index words: Panicum virgatum (L.), IVDMD, Phenotypic selection.

$S^{w}$ WITCHGRASS, Panicum virgatum L., is a warmseason, cross-pollinated perennial grass that is native to the prairies and plains of North America where it is used in pastures and rangelands for grazing and prairie hay. Eberhart and Newell (1959) and Newell and Eberhart (1961) reported that substantial genetic variability existed between and within endemic strains of switchgrass for seed quality, leaf rust reaction, leaf height, plant height, seed yield, plant yield and forage quality. Heritability estimates for visually rated forage quality ranged from 0.27 to 0.70 (Newell and Eberhart, 1961).

'Contribution of the Dep. of Agronomy, Univ. of Nebraska, and AR, SEA, USDA. Published as Paper No. 5943. Journal Series, Nebraska Agric. Exp. Stn. Received 16 May 1980

${ }^{2}$ Research agronomist, AR-SEA/USDA; George Holmes Professor of agronomy, Univ. of Nebraska; and supervisory research geneticist, ARSEA/USDA, Lincoln, NE 68583

${ }^{3}$ Mention of a trademark, proprietary product, or vendor does not constitute a guarantee or warranty of the USDA and does not imply its approval to the exclusion of other products or vendors that may also be suitable.
Tilley and Terry's (1963) in vitro procedure for estimating the dry matter digestibility of forages has permitted grass breeders to quantify the digestibility of a large number of genotypes. Heritability estimates for in vitro dry matter digestibility (IVDMD) have been reported for both cool- and warm-season grasses. Among the warm-season grasses, heritability estimates for dry matter digestibility were reported for big bluestem, $A n$ dropogon gerardi Vitman (Ross et al., 1975); indiangrats, Sorghastrum nutans (L.) Nash (Vogel et al., 1981); bermudagrass, Cynodon dactylon (L.) Pers. (Burton and Monson, 1972); and rhodesgrass, Chloris gayana Kunth (Quesenberry et al., 1978). Although the methods of estimating heritabilities for these grasses varied, all of the heritability estimates were positive and indicated that substantial genetic variability for dry matter digestibility existed within each species. 'Coastcross l' bermudagrass, selected for high dry matter digestibility (nylon bag method) averaged over $12 \%$ more digestible dry matter than 'Coastal' bermudagrass (Burton et al., 1967). When grazed by yearling steers, Coastcross 1 produced an improvement of $30 \%$ in average daily gains (Chapman et al., 1971). Burton (1974) showed that recurrent phenotypic selection significantly increased forage yields of pensacola bahiagrass, Paspalum notatum Fluegge var. saurae, and recently (Burton, 1979) he suggested that this procedure could be used to improve the dry matter digestibility of pearl millet, Pennisetum americanum (L.) Leeke.

The purposes of this study were to determine if phenotypic selection for IVDMD could be used to improve the forage quality of switchgrass and to obtain estimates of the heritability of IVDMD in switchgrass.

\section{MATERIALS AND METHODS}

In 1973 adjacent space-transplanted nurseries of switchgrass strains 'ey' and 'ff' were established at the Mead Field Laboratory at Mead, Nebr. These experimental strains were developed by L. C. Newell (Newell and Moline, 1978) and orginated from collections made in southeast Nebraska and northeast Kansas. Both were similar to 'Pathfinder' in maturity, origin, and breeding. Each nursery consisted of 28 rows with 40 plants/row. Spacings were $1.1 \mathrm{~m}$ within and between rows.

In 1974 about 400 vigorous plants were sampled for forage quality in each of the two nurseries. Plants were sampled when panicles were beginning to emerge from the boot. Five tillers were cut $5 \mathrm{~cm}$ above the base of the plant, dried in a forced draft oven at about $65 \mathrm{C}$, ground in a Wileys mill to pass a 20 mesh screen, and analyzed for IVDMD (Tilley and Terry, 1963). The samples were also analyzed for crude protein $(\% \mathrm{~N} \times$ 6.25)(A.O.A.C., 1960).

In 1975 and 1976 four plants were sampled in each of the 56 nursery rows and were analyzed for forage IVDMD using the same procedure as in 1974 . The plants sampled had the highest 
and lowest IVDMD and protein percentages in each row in 1974; thus, a total of 224 plants were sampled in 1975 and 1976. However, for all 3 years of sampling, IVDMD percent ages were available on only 220 plants.

In 1976, 12 and 13 plants were randomly selected from the 28 ff and 28 ey plants, respectively, that had been identified as high-IVDMD in 1974. Similarly 13 and 12 low-IVDMD plants were randomly selected from the low-IVDMD plants of ey and $\mathrm{ff}$, respectively. Two ramets from each of 25 high-IVDMD plants were transplanted into an isolated polycross (PC) nursery. The experimental design of the PC nursery was a randomized complete block with one ramet of each plant in each of two blocks. A comparable procedure was used to establish a lowIVDMD PC nursery. The ey and ff selections were polycrossed together because they were similar in maturity and origin, and there were no distinctive differences between the two strains.

In 1976 open-pollinated (OP) seed was harvested from the 50 selected plants in the original selection nurseries. In 1977 seed was harvested from the plants in the high- and low- IVDMD PC nurseries. All seed was harvested and handled on an individual plant basis. The following four experimental strains were developed by compositing an equal amount of seed by weight from each plant of the appropriate strain: high-IVDMD PC, high-IVDMD OP, low-IVDMD PC, and low-IVDMD OP.

The four strains and Pathfinder were established in a replicated sward trial. The experimental design was a randomized complete block with seven replications. Plots were $4.3 \mathrm{~m}$ long and $1.2 \mathrm{~m}$ wide with rows spaced $15 \mathrm{~cm}$ apart within the plots. The nursery was seeded on 18 May 1978 and was sprayed on 19 May with $2.2 \mathrm{~kg} / \mathrm{ha}$ (AI) atrazine [2-chloro-4-(ethylamino) -6-(isopropylamino)- $S$-triazine] for weed control. The plots were fertilized with $112 \mathrm{~kg} / \mathrm{ha}$ of $\mathrm{N}\left(\mathrm{NH}_{4} \mathrm{NO}_{3}\right)$ on 2 August and harvested on 5 Sept. 1978 when most of the panicles were emerging from the boot. Plots were harvested with a flail-type plot harvester at a cutting height of $10 \mathrm{~cm}$. The harvester took a 0.9 - $\mathrm{m}$ swath out of the center of each 1.2 - $\mathrm{m}$ wide plot. The plots were separated on the ends by $1.2 \mathrm{~m}$ wide alleys seeded to Pathfinder which were harvested prior to the plots. Six grab

Table 1. Mean IVDMD values of the 25 high- and 25 lowIVDMD plants selected for use as parents in the switchgrass divergent selection experiment.

\begin{tabular}{|c|c|c|c|c|}
\hline \multirow[b]{2}{*}{ Strain } & \multicolumn{4}{|c|}{ Mean IVDMD $\pm \mathbf{s}_{\overline{\mathbf{x}}}$} \\
\hline & 1974 & 1975 & 1976 & Mean \\
\hline & \multicolumn{4}{|c|}{$-1-1$} \\
\hline 25 high IVDMD plants & $55.1 \pm 0.3$ & $51.1 \pm 0.7$ & $46.5 \pm 0.8$ & 50.9 \\
\hline \multirow{4}{*}{$\begin{array}{l}\text { Mean of selected high } \\
\text { and low IVDMD plants } \\
\text { Original population of } \\
220 \text { sampled plants }\end{array}$} & $45.8 \pm 0.7$ & $46.6 \pm 0.7$ & $42.8 \pm 0.8$ & 45.1 \\
\hline & 50.5 & 48.8 & 44.6 & 48.0 \\
\hline & & & & \\
\hline & $51.1 \pm 0.3$ & $49.3 \pm 0.3$ & $43.9 \pm 03$ & 48.1 \\
\hline
\end{tabular}

samples, composited from each plot after yields were weighed, were used to determine percentages of dry matter, IVDMD, and crude protein. Duplicate IVDMD analyses were made and the means of both analyses were used in the statistical analyses.

In 1979 the sward nursery was sprayed with $13.4 \mathrm{~kg} / \mathrm{ha}$ (AI) DCPA (dimethyl tetrachloroterephthalate) and with $2.2 \mathrm{~kg} / \mathrm{ha}$ (AI) atrazine on 1 and 15 May, respectively, for weed control. It was fertilized with $112 \mathrm{~kg} / \mathrm{ha} \mathrm{N}\left(\mathrm{NH}_{4} \mathrm{NO}_{3}\right)$ on 14 May. The nursery was harvested on 23 July 1979 when about one-third of the tillers in the nursery had panicles emerging from the boot. There were no apparent maturity differences among the strains.

Realized heritabilities (Falconer, 1960) for high and low IVDMD were calculated over years with the following equation: $\mathrm{H}=\left[\left(\overline{\mathrm{X}}_{\mathrm{O}}-\mathrm{X}_{\mathrm{o}}\right) / \overline{\mathrm{X}}_{\mathrm{o}}\right] /\left[(\overline{\mathrm{X}} \mathrm{ps}-\overline{\mathrm{X}} \mathrm{p}) / \overline{\mathrm{X}}_{\mathrm{p}}\right] . \overline{\mathrm{X}}$ os is the mean of the polycross progeny of the selkected plants, Xo is the mean of the high and low IVDMD OP strains, $\mathrm{X} p$ is the mean of the 25 selected parent plants, and $\overline{X p}$ is the mean of the parent population of 220 sampled plants. $\bar{X}$ o was used as an estimate of the mean of the progeny from unselected parents.

\section{RESULTS AND DISCUSSION}

The means of the high and low IVDMD parent plants in 1974,1975 , and 1976 are listed in Table 1 . Over years, the high IVDMD parents were 5.8 percentage points higher in IVDMD than the low parents. The reason for the decrease in the difference between the high and low IVDMD plants over years is not known.

The high IVDMD PC strain had significantly higher IVDMD than the other strains in both 1978 and 1979 (Table 2). The IVDMD values of the seeded plots were higher in 1979 than in 1978 , probably because harvest was at an earlier stage of maturity in 1979. In 1978 there were no significant differences among the other four strains, but in 1979 the high IVDMD OP strain was significantly higher in IVDMD than both low IVDMD strains. In both years Pathfinder was only 0.2 percentage points higher in IVDMD than the mean of the high and low IVDMD OP strains and it can be considered representative of the unselected parent population. In both years the strains ranked in the order anticipated, i.e., high IVDMD PC, high IVDMD OP, strain unselected for IVDMD (Pathfinder), low IVDMD OP, and low IVDMD $P C$. Twice as much gain from selection was expected from the PC strains with both male and female parents selected, as from the OP strains with only the female parent selected. Relative to OP clones, the selected PC clones had more than twice as much change from selection for high IVDMD but less than twice as much change for low IVDMD (Table 2). The realized heritability for

Table 2. Mean forage yields, IVDMD, protein, and dry matter percentages for switchgrass strains derived from divergent selection for IVDMD in 1978 and 1979.

\begin{tabular}{|c|c|c|c|c|c|c|c|c|}
\hline \multirow[b]{2}{*}{ Strain } & \multicolumn{2}{|c|}{ IVDMD } & \multicolumn{2}{|c|}{ Yield } & \multicolumn{2}{|c|}{ Protein } & \multicolumn{2}{|c|}{ Dry matter } \\
\hline & $1978^{*}$ & $1979^{*}$ & $1978^{*}$ & $1979^{*}$ & $1978^{*}$ & $1979^{*}$ & $1978^{*}$ & $1979^{*}$ \\
\hline & $\ldots$ & $-\ldots$ & $-\ldots$ & - & $-1-3$ & - & 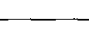 & -—- \\
\hline \multicolumn{9}{|l|}{ Means: $\dagger$} \\
\hline 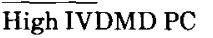 & $47.2 \mathrm{a}$ & $55.8 \mathrm{a}$ & $7.26 \mathrm{a}$ & $9.30 \mathrm{a}$ & $9.8 \mathrm{a}$ & $10.3 \mathrm{a}$ & $32 \mathrm{~b}$ & $31.5 \mathrm{c}$ \\
\hline High IVDMD OP & $45.3 b$ & $54.6 \mathrm{~b}$ & $7.44 \mathrm{a}$ & $9.53 \mathrm{a}$ & $9.5 \mathrm{bc}$ & $10.1 \mathrm{a}$ & 34 a & $33.2 \mathrm{ab}$ \\
\hline Pathfinder & $44.8 \mathrm{~b}$ & $54.0 \mathrm{bc}$ & $7.11 \mathrm{a}$ & $9.06 \mathrm{a}$ & $9.4 \mathrm{c}$ & $10.0 \mathrm{a}$ & $33 \mathrm{ab}$ & $33.6 \mathrm{a}$ \\
\hline Low IVDMD OP & $43.8 \mathrm{~b}$ & $52.9 \mathrm{c}$ & $7.80 \mathrm{a}$ & $9.28 \mathrm{a}$ & $9.3 \mathrm{c}$ & $9.8 \mathrm{a}$ & $34 \mathrm{a}$ & $33.2 \mathrm{ab}$ \\
\hline Low IVDMD PC & $43.3 \mathrm{~b}$ & $52.8 \mathrm{c}$ & $7.33 \mathrm{a}$ & $9.21 \mathrm{a}$ & $9.7 \mathrm{ab}$ & $10.3 \mathrm{a}$ & $33 \mathrm{ab}$ & $32.8 \mathrm{~b}$ \\
\hline C.V., \% & 3.8 & 1.06 & 6.0 & 5.8 & 2.3 & 4.7 & 2.7 & 2.0 \\
\hline
\end{tabular}

* Means followed by the same letter are not significantly different at the 0.05 level of probability as determined by Duncan's Multiple Range Test. $\uparrow \mathrm{OP}=$ open pollinated seed harvested from selected plants in the original selection nursery. $\mathrm{PC}=$ polycross seed harvested from all plants in isolated poly. cross nurseries. 
high IVDMD was $\mathrm{H}=0.59$; for low IVDMD it was $\mathrm{H}=$ 0.55 .

Strains did not differ significantly for forage yield in either 1978 or 1979 . The 1979 yields were greater because 1978 was the establishment year. The high yields are indicative of the potential of switchgrass as a warm-season forage crop when properly managed. The strains differed significantly for protein content in 1978 but not in 1979 . The differences among strains for protein content in 1978 were small and did not appear to be related to IVDMD. Differences among strains were small but significant in both years for dry matter percentage. The high IVDMD PC strain had the lowest dry-matter percentage for both years.

In the analysis over years, (not shown), strains differed significantly for dry matter, IVDMD, and protein percentage. Years were a significant source of variation for yield, IVDMD, and protein percentage. Strains $\times$ years interactions were not significant for any of the traits studied.

In one cycle of phenotypic selection, we have significantly improved the IVDMD of switchgrass. Whether this improvement in IVDMD can improve animal performance remains to be tested. The increase in IVDMD was achieved without any loss of yield or decrease in protein content. Additional cycles of selection should result in additional improvement in IVDMD.

Our selection procedure was actually a modified form of restricted recurrent phenotypic selection (Burton, 1974). The selection nursery was stratified into rows instead of blocks, the better plants in each row were sampled at the same physiological stage, the best plant was selected from a selection unit or row, and the best plants were polycrossed in isolation. In future cycles of selection we expect to follow essentially the same procedure except that selection blocks may be as small as 20 plants per block. Each cycle will take 3 years with establishment in Year 1 , evaluation and selection in Year 2, and polycrossing in Year 3. Since differences between analyses is one of the primary sources of experimental error in the IVDMD procedure (Holt et al., 1979), we can have all the samples from a selection block in the same run. In summary phenotypic selection can be effectively used to improve the forage quality of switchgrass.

\section{REFERENCES}

1. Association of Official Agricultural Chemists. 1960. Official methods of analyses of the A.O.A.C. 9th ed. A.O.A.C. Washington, D.C.

2. Burton, G. W. 1974. Recurrent restricted phenotypic selection in creases forage yield of Pensacola bahiagrass. Crop Sci. 14:831 835 1979. Modifying recurrent restricted phenotypic selection to improve forages. Agron. Abstr. p. 57.

4. -. . R. H. Hart, and R. S. Lowrey. 1967. Improving forage quality in bermudagrass by breeding. Crop Sci. 7:329 332.

5. and W. G. Monson. 1972. Inheritance of dry matter digestibility in bermudagrass, Cynodon dactylon (L.) Pers. Crop Sci. 12:375:378.

6. Chapman, H. D., W. H. Marchant, G. W. Burton, W. G. Monson, and P. R. Utley. 1971. Performance of steers grazing Pensacola bahia, Coastal and Coastcross 1 bermuda grasses. J. Animal Sci. $32: 374$.

7. Eberhart, S. A., and L. C. Newell. 1959. Variation in domestic collections of switchgrass. Agron. J. 51:613-616.

8. Falconer, D. S. 1960. Introduction to quantitative genetics. The Ronald Press Company, New York.

9. Holt, E. C., W. C. Fllis, and G. R. Engdahl. 1979. Forage sampling factors influencing the variability of in vitro fermentation results of grass selections. Crop Sci. 19:219-221.

10. Newell. L. C., and S. A. Eberhart. 1961. Clone and progeny evaluation in the improvement of switchgrass, Panicum virgatum L. Crop Sci. 1:117-121.

11. - . and W. J. Moline. 1978. Forage quality evaluation of twelve grasses in relation to season for grazing. Nebr. Res. Bull. 283.

12. Quesenberry, K. H., D. A. Sleper, and J. A. Cornell. 1978. Heritability and correlations of IVDMD, maturity, and plant height in rhodesgrass. Crop Sci. 18:847 850

13. Ross, J. G., R. T. Thaden, and W. L. Tucker. 1975. Selection criteria for yield and quality in big bluestem grass. Crop Sci. 15:303 306

14. Tilley, J. A., and R. A. Terry. 1963. A two-stage technique of the in vitro digestion of forage crops. J. Br. Grassl. Soc. 18:104-111

15. Vogel, K. P., H. J. Gorz, and F. A. Haskins. 1981. Heritability estimates for forage yield, in vitro dry matter digestibility, crude protein, and heading date in indiangrass. Crop Sci. 21:35-38. 